\title{
CONSUMERISM OF LEISURE CLASS IN SINGAPORE IN KEVIN KWAN'S CRAZY RICH ASIANS: A SOCIOLOGICAL APPROACH
}

\author{
Agni Nurwidia Setiadi ${ }^{1}$, ResneriDaulay $^{2}$ \\ ${ }^{I}$ Student of English Literature Department, Faculty of Literature, Culture and Communication, \\ Universitas Ahmad Dahlan \\ ${ }^{2}$ Lecturer of English Literature Department, Faculty of Literature, Culture and Communication, \\ Universitas Ahmad Dahlan
}

\section{ARTICLE INFO}

Received:2021-01-06

Accepted: 2021-03-19

Published: 2021-03-22

Volume: 5

Issue: 1

DOI:

https://doi.org/10.33019/lire.v

3i2.101

KEYWORDS

Leisure Class, Consumerism, Conspicuous Leisure,

Conspicuous Consumption

ABSTRACT

This research entitled "Consumerism of Leisure Class in Singapore in Kevin Kwan's Crazy RichAsians: A Sociological Approach". The purpose of this study is to analyze the leisure class reflected in Singapore in thenovel Crazy RichAsians. In addition, the aim of this research is to reveal the consumerism of leisure class in Crazy Rich Asians. This novel contains the a spect about the style of consumer in Singapore. The research uses qualitative method to analyze the data. This study uses the mimetic approach by M.H. Abrams and two main concepts of theory of leisure class by Thorstein Veblen, these are conspicuous leisure and conspicuous consumption. The research applies the data of Singa poreans leisure class in the book Understanding Singaporeans: Values, Lifestyle, Aspirations and Consumption Behaviours by Keng et al. This study also applies the concept of uniquely Singaporean mindset in the book entitled The Cult of the Luxury Brand: Inside Asia 's Love affair with Luxury by Chadha and Paul as a tool to analyze the consumerism of leisure class in the novel Crazy Rich Asians. In this study, the researcher finds two main results. First, this study indicates conspicuous leisure as a signal of leisure class in Crazy Rich Asians based on seven leisure activities of Singaporean. They are sports, social, self-improvement, various charity, tra vel, home, and other activities. Second, the study discovers the consumerism of leisure class in Crazy Rich Asians and uniquely Singaporean mindset as a main result of leisure class' consumerism in Singapore reflected in Crazy RichAsians.
\end{abstract}

uthor: ResneriDaulay E-mail: resneri.daulay@enlitera.uad.ac.id

\section{INTRODUCTION}

Literary work is assumed as a social world that uses language as the platform. It creates lives that mostly contain social reality. The literary work is written by the authors in a certain range of times connect directly with the social conditions at that period. Through literary work, the author is able to deliver the condition of his/her society. According to Arjun Dubey, "we all know literature mirrors society. What happens in society is reflected in literary works in one form or another..." (2013: 84). In other words, literary work is a platform to explain the condition of society. It is the expression of society.

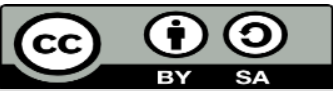

This work is licensed under Creative Commons Attribution-ShareAlike 4.0 Internasional. Copyright @ 2021, Agni Nurwidia Setia di, Resneri Daulay 
Kevin Kwan is one of the authors who created literary work that correlates with his society. Kwan has already written a trilogy of Crazy Rich Asians. The first novel is entitled Crazy Rich Asians. The second is China Rich Girlfriend. Then, the last is Rich People Problems. These novels are successfully bringing Kwan to the list of 100 most influential people of 2018 on Time magazine. Based on the article on time.com stated that

“...in his trilogy of novels about contemporary Asians, which began with 2013's Crazy Rich Asians, Kevin Kwan makes these small things matter, not for their glitz but for what those choices reveal about our inner lives and histories. It's no surprise that his books are bestsellers..." (Constance, "Kevin Kwan“, par.1).

This theme succeeded brings Kevin Kwan to be one of the famous Asian authors world wide. The trilogy novel is a fundamental milestone for Kevin Kwan. This is an international bestseller novel. It has been translated into several languages. On June 2016, the Crazy Rich Asians Indonesia version is published by Gramedia Pustaka Utama. The title is changed into Kaya Tujuh Turunan. Based on the article by detik.com, the total number of the novels sold was 28.000 copies. This is the statement from Public Relations Gramedia Pustaka Utama (Agnes, Tia, “Terjual 28 Ribu Kopi, Ini kehebatan 'Crazy Rich Asian"', par.7). This fact is evidence that Kwan succeeded deliver his works into the world. Then, in August 2018 Crazy Rich Asians is turned into a film by Warner Bros.

Simply, these are several reasons why the researcher thought that Kevin Kwan is a successful author. The trilogy novels are phenomenal. It is interesting how an Asian could have a stage in the global, as we know that Hollywood used to be more popular. Then, Asian society with the leisure class becomes popular as well. However, the researcher decided to focus on the first novel entitled Crazy Rich Asians. Generally, Crazy Rich Asians by Kevin Kwan is the novel that has a purpose to introduce Asian leisure class lifestyle to the world. Most of the characters care about their wealth and position in social life. Their behavior should be the signal of their position as a leisure class. The leisure class is a title for those people who able to gain power because their wealth. For that reason, the leisure class is able to consumed their time and money unproductively (Veblen, 1899: 2).

Crazy Rich Asians contains the concept of consumption. Consumption is an essential factor in this novel. The way each character spends their time and money is the evidence of their position as the leisure class. This research focuses on Singapore, for Singapore has a relation with the definition 
of Asian in the novel Crazy Rich Asians by Kevin Kwan. Basically, Kwan mentioned the other countries of Asia in the novel. However, Singapore is close with the definition of elite Asian. There are several parts in the novel Crazy Rich Asians that described the wealthy characters who lived in Singapore. In addition, the researcher is able to get the information about the Singaporean character based on the family tree in the opening page of the novel.

Since there are several facts about Singapore relate to the story in the novel Crazy Rich Asians, the researcher decides to discuss the consumerism of leisure class in Singapore reflected in the novel Crazy Rich Asians. The researcher is used the mimetic approach by M.H. Abrams. Since mimetic approach applies a sosiological life in a region or country, then how consumerism of the Singaporean will be seen in this research. In addition, the researcher is applied the theory of leisure class by Thorstein Veblen to analyze the leisure class in the novel Crazy Rich Asians. The researcher argues that the theory of leisure class is able to be the tools to discover the consumerism of leisure class in the novel Crazy Rich Asians. The researcher found a previous study entitled "The Representation of Veblen's Concept from the "Theory of Leisure Class" in Dreiser's "Sister Carrie"” by M.A. Oliver Steinert-Lieschied from University of Göttingen. This seminar paper discovered the theory of leisure class in the book Sister Carrie. The writer used the concept of conspicuous leisure and conspicuous consumption in the seminar paper. The main analysis of this paper are Carrie's obsession for clothes and Carrie's attitude towards work (Oliver Steinert-Lieschied, M.A, 2006).

\section{LITERATURE REVIEW}

The researcher collected previous researches that have been conducted to investigate Crazy Rich Asians. The first undergraduate thesis is entitled "The Struggle of the Main Character to Regain Her love as Reflected in Kevin Kwan's Crazy Rich Asians: An Objective Approach" written by Nofiana Ambar Pratiwi from English education study department, Universitas Ahmad Dahlan (2018). The object of the research is the struggle of the main character to regain his love (Pratiwi, 2018: xi). The results of the research are: there are five intrinsic elements of the novel Crazy Rich Asians, the struggle of Nick Young to regain his love, the moral value of the novel.

The second researcher is Dwi Rohmawati from English Education, Universitas Muhammadiyah Surakarta (2018). The title is “Family Conflicy Reflected in Kevin Kwan's Crazy

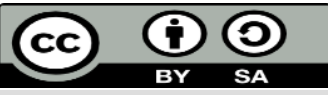


Rich Asians (2013): A Sociological Approach". This thesis discussion is about family conflict (Rohmawati, 2018: 1). The third undergraduate thesis was written by Antonio Winanti from English language and literature study program, Indonesia University of Education entitled "The Representation of Chinese Characters in Kevin Kwan's Crazy Rich Asians (2013)". This research discussed Chinese characters in the novel Crazy Rich Asians. Then, the researcher used a qualitative approach and textual analysis method. This undergraduate thesis used the theory of representation and hybridity (Antonio, 2019).

Those works are also used Crazy Rich Asians by Kevin Kwan. The first related study is analyzed the struggle of the main character in the novel by using objective approach. The second related study is focused on familiy conflict in the novel by apply ing the sociological approach. The third work is discussed about the representation of chinese character in the novel by using qualitative approach.

\section{METHODOLOGY}

To analyze this undergraduate thesis, the researcher uses a descriptive qualitative method. According to Earl Babbie (303), qualitative research is a scientific method of observation to gather nonnumerical data. There are three materials will be explained in this undergraduate thesis, there are:

\subsection{Data and Source of Data}

The researcher has two sources to collect the data for this research. It is the primary source and secondary source. The primary source is the novel Crazy Rich Asians by Kevin Kwan in form of words, sentences, etc. Then, for the secondary source, the researcher takes from the other sources such as other undergraduate thesis, journal, books that related to the research, and internet sources.

\subsection{Method of Collecting Data}

In the method of collecting data, the researcher reads the novel Crazy Rich Asians repeatedly, sheet by sheet to understand the story. This study takes data in the form of sentence, statement, and explanation in the novel. In addition, while reading a novel, the researcher makes several notes that contain the consumerism of the leisure class in the novel. This undergraduate 
thesis also discusses the relationship of the story in the novel with a real condition in Singapore, therefore the researcher will read and collect data about Singapore that became the setting of the novel.

\subsection{Method of Analyzing Data}

After the data are collected, the next method is analyzing data. The techniques used by the writer to analyze the data are:

a. The researcher analyzes the leisure class reflected in Singapore in the novel titled Crazy Rich Asians by Kevin Kwan. The researcher applied the concept of conspicuous leisure and conspicuous consumption in the theory of leisure class by Thorstein Veblen to define the leisure class. The researcher used a mimetic approach by M.H. Abrams to find out the leisure class reflected in Singapore in the novel Crazy Rich Asians. The researcher used the book entitled Understanding Singaporeans: Values, Lifestyle, Aspirations and Consumption Behaviours as the data of Singaporean leisure activity in a group of high personal income. The leisure actvities are sports, social and culture activities, self-improvement activities, charity activities, travel actvities, home entertainment activities, and other activities. The researcher used the data of Singaporean leisure activities to classify the leisure class in Singapore reflected in Crazy Rich Asians by Kevin Kwan.

b. The researcher analyzes the consumerism of leisure class reflected in Singapore in the novel titled Crazy Rich Asians. The researcher used the concept of conspicuous leisure and conspicuous consumption in the theory of leisure class by Thorstein Veblen. The study applied a mimetic approach. The researcher applied the concept of the uniquely Singapo rean mindset in the book entitled The Cult of the Luxury Brand: Inside Asia's Love affair with Luxury by Chadha and Paul Husband to discover the consumerism of leisure class in Singapore reflected in Crazy Rich Asians by Kevin Kwan.

\section{RESULTS AND DISCUSSION}

In this chapter, the researcher would like to analyze the leisure class in Singapore reflected in the novel Crazy Rich Asians by Kevin Kwan. In the discussion, the researcher used two signals of leisure class in the theory of leisure class by Thorsein Veblen. Then, the researcher used the book entitled Understanding Singaporeans: Values, Lifestyle, Aspirations and Consumption Behaviours as the 
supporting data to discover connection between leisure class in Crazy Rich Asians and Singapore. Then, the researcher analyzed the consumerism of leisure class reflected in Singapore in Kwan's Crazy Rich Asians. In the discussion, the researcher used two signals of leisure class in the theory of leisure class by Thorsein Veblen. Then, the researcher used the book entitled The Cult of the Luxury Brand: Inside Asia's Love affair with Luxury as the supporting data to discover connection between the consumerism of leisure class in Crazy Rich Asians and Singapore. This discussion devided into two part:

\section{A. The Leisure Class in Singapore Reflected in Kevin Kwan's Crazy Rich Asians}

In the theory of the leisure class by Thorstein Veblen, he described the definition of the leisure class and its signal. The signal of leisure class are conspicuous leisure and conspicuous consumption. As a result, the researcher will be analyzing the leisure class in Singapore in Crazy Rich Asians by identifying the conspicuous leisure and conspicuous consumption on it. Besides, the researcher used the data from a book entitled Understanding Singaporeans: Values, Lifestyle, Aspirations and Consumption Behaviours by Keng et al as a supporting source to find out the real leisure class in Singapore. Hereafter, the researcher applied a mimetic approach by M.H. Abrams to discuss the leisure class reflected in Singapore in Crazy Rich Asians.

However, as the researcher mentioned before, the research is used the data from Understanding Singaporeans: Values, Lifestyle, Aspirations and Consumption Behaviours written by Keng et al as supporting data. One of the main findings in the book Understanding Singaporeans: Values, Lifestyle, Aspirations and Consumption Behaviours is the leisure activities of Singaporeans. The authors of this book categorized the leisure activities into seven types, there are: "sports, social and cultural activities, self-improvement, charity/social work/community services, travel, home entertainment, and other types of activities" (Keng et al., 2004: 97). Since the focus of this undergraduate thesis is leisure class. The researcher decided to concern about the survey of leisure activities based on personal income, especially for the data categorized in the highest personal income. The authors of the book Understanding Singaporeans: Values, Lifestyle, Aspirations and Consumption Behaviours are classifying the highest personal income in range personal monthly incomes of more than $\$ 5000$ (Keng et al., 2004). In other words, there are about 105 respondents reported gross personal income above $\$ 5000$. The researcher thought the data on this book is quite enough to become a supporting 
data about conspicuous leisure and conspicuous consumption in Singapore ref lected in the novel Crazy Rich Asians by Kwan. The data of two signals of leisure class in the novel is the basic formulation to analyze the leisure class in Singapore in the novel Crazy Rich Asians. As a result, the researcher is classifying the analysis process of leisure class in Singapore reflected in the novel Crazy Rich Asians based on the leisure activities in the book Understanding Singaporeans: Values, Lifestyle, Aspirations and Consumption Behaviours. There are:

\section{A.1. Sport Activities}

The author of Understanding Singaporeans: Values, Lifestyle, Aspirations and Consumption Behaviours suggested that "golfing categorized as an expensive sport in Singapore" (Keng et al., 2004: 103). The author of Crazy Rich Asians was not exactly mentioning sports activity situations. However, Kwan undirectly mentioned sports activity in several situations. The first data, Kwan created situation that display Eleanor Young, Felicity Leong, and their family had a trip to London. On that part, they rejected by a general manager of The Calthorpe hotel because he didn't believe that they booked Lancaster suite. Then, Felicity Young decided to call her husband -Harry Leong in Singapore. The fact is her husband know the owner of the hotel, her husband said, "Yes, I think that's it! I played golf with Rupert what's his name and a few other Brits last month in California, and I remember him telling me all about his place. Felicity, I have an idea. I'm going to call this Rupert fellow. Just stay put and I'll call you back.” (Kwan, 2013: 11).

Kwan created character Harry Leong as Singaporean who extremely wealthy and powerful. As evidence, Harry Leong bought the hotel Calthorpe after he got the news that her wife rejected by the hotel. Then, Kwan also mentioned that Harry Leong knew the owner of the Calthorpe hotel, Rupert. Through the quotation, the researcher is able to know that Harry played golf with Rupert when they were in California. This is data that represents golf as a sports activity for Harry Leong. It is relevant to the data from Understanding Singaporeans: Values, Lifestyle, Aspirations and Consumption Behaviours that suggested golf as an expensive sports activity (Keng et al., 2004: 103). It is popular in a group that earned personal monthly income of more than $\$ 5000$. Also, Kwan mixed this type of expensive sport with the location where Harry and Rupert were playing, California. It seemed to 
confirm that Harry Leong categorized as a person who has high personal income in the novel Crazy Rich Asians.

This data is supported by the statement from a character named Comstessee Isabelle. She is Harry Leong's daughter friend -Astrid Leong. She mentioned information about Leong's income on her conversation with Marie-Hĕlěne:

"The Leongs are a Chinese family from Singapore."

"Ah yes, I've heard that Chinese are getting quite rich these days. In fact, I read that there are now more millionaires in Asia than in all of Europe. Who would have ever imagined?"

"No, no, I'm afraid you don't quite understand. Astrid's peo ple have been wealthy for generations. Her father is one of Laurent's biggest clients," Isabelle whispered. (Kwan, 2013:43)

This conversation contains information that Leong's categorized as a family with high income. The researcher thought Harry Leong's monthly income is more than $\$ 5000$. In conclusion, Harry Leong is a character in the novel Crazy Rich Asians who earned personal income more than $\$ 5000$. He consumed his time by playing golf in California. It is relevant to the data from Understanding Singaporeans: Values, Lifestyle, Aspirations and Consumption Behaviours that assumed golf as a popular sport activity in Singaporean group who earned personal monthly income more than $\$ 5000$ (Keng et al., 2004: 103). In addition, playing golf be able to categorize as conspicuous of leisure based on theory of the leisure class. Veblen described that the evidence of conspicuous leisure is, "...the knowledge of the various forms of domestic music and other household art; of the latest properties of dress, furniture, and equipage; of games, sports, and fancy-bred animals, such as dogs and racehorses "(Veblen, 1899:22). Simply, the researcher is able to found the data that correlate with this fact in the novel Crazy Rich Asians through the character named Harry Leong.

\section{A.2. Social and Cultural Activities}

The author of Understanding Singaporeans: Values, Lifestyle, Aspirations and Consumption Behaviours suggested that, the group in high personal income has a high percentage on "the visited book store $(33,3 \%)$, attend concerts/performances $(23,1 \%)$, visit art galleries/exhibitions $(12,8 \%)$, drawing/painting (7,7\%)" (Keng et al., 2004:108). The researcher found the social and cultural activities reflected in Singapore in the novel Crazy Rich Asians, firstly, “...Nick turned to Rachel, 
looking a little sheepish. "I hope it's okay...but it's not just the family. My grandmother decided to have a small party, all arranged at last minute, apparently, because her tan hua flowers are going to bloom tonight"(Kwan, 2013:171).

This quotation contains information about the social and cultural activity. It is an exhibition of tan hua flowers held by Nick's grandmother, Shang Su Yi. This exhibition attended by most characters in the novel Crazy Rich Asians. Kwan created this exhibition to expose the wealth in each character. Kwan described this exhibition in one full chapter entitled Rachel and Nick: Tyersall Park. Tyersall Park is a place where the exhibition was held. Kwan described Tyersall Park as, "it wasn't house. It was more like palace. The front driveway was lined with cars, almost all of which were large and European - Mercedes, Jaguars, Citroëns, Rolls Royce, many with diplomatic medallions and flag"(Kwan, 2013: 158).

It is about $12,8 \%$ of respondents with personal monthly income more than $\$ 5000$ attended exhibition while only 5\% who earned less than $\$ 1000$ engaged in an exhibition (Keng et al., 2004:108). This exhibition is non-labour activity. They did not attend tan hua party to earned money. The guests in tan hua exhibition are coming from a group with high income. They came into tan hua exhibition because they have ability to see flowers are in bloom and not bothered by the need to make money. It is correlated with the statement by Veblen (1899: 21), in certain communities who exemption from labour activity consumed their time as evidence of wealth and power. On the tan hua exhibition, the guests were talking about their wealth. As Kwan has written in the conversation between Oliver T'sien and Astrid Leong:

"Holy Mary Mother of Tilda Swinton, look at those earrings! Wherever did you get them?"

"Stephen Chia's... they're VBH," Astrid said, knowing he would want to know the designer was.

"Of course they are. Only Bruce could have dreamed up something like that.

They must have cost at least half a million dollars..."

(Kwan, 2013: 185).

\section{A. 3. Self-Improvement Activities}

Based on the book entitled Understanding Singaporeans: Values, Lifestyle, Aspirations and

Consumption Behaviours, the respondents with personal monthly income more than $\$ 5000$ have a higher percentage of all self-improvement activities, except attend modeling and cooking classes 
(Keng et al., 2004:113). However, the researcher focused on the attend language classes ac tivity. For a reason, the researcher only found that aspect in the novel Crazy Rich Asians. Basically, Kevin Kwan did not describe the language classes activity. He only mentioned in certain situations. For example:

"...my father was a businessman, but he never wanted me to learn about financial matters. He always said that within a hundred years, China would become the most powerful nation the world has ever seen. And that is something I always repeated to my children and grandchildren. Isn't that right, Nicky?" "Yes, Ah Ma. That's why you made me learn my Mandarin," Nick confirmed.(Kwan, 2013: 335)

This is a dialogue between Nick Young and his grandmother - Shang Su Yi. This quotation represents the Mandarin language as a self-improvement language. On this data, the researcher did not finding the situation about attend language classes directly. Kwan was not explaining about self improvement activity specifically.

However, the researcher is able to know that Mandarin language is quite important. For one of the main characters named Colin Khoo said that: "I had to take a special test in Mandarin. They don't think I'm good enough, even though I took classes every day in LA" (Kwan, 2013: 250). According to that quotation, the researcher found Colin Khoo took Mandarin classes frequently when he was in LA. Colin Khoo is one of the main character in the novel Crazy Rich Asians. Kwan created Colin Khoo as:

"AH-LA-MAAAK! Colin Khoo is Khoo Teck Fong's grandson! He comes from one of reeee-chest families in the world!..."(Kwan, 2013:139)

Based on the quotation, the researcher assumed that Colin Khoo is a character who earned high personal income. Kwan created Colin as a character who comes from the richest family. As a conclusion, Colin Khoo is a wealthy character who took Mandarin classes frequently as his selfimprovement activity. The data about Colin Khoo who attending Mandarin classes in LA in the novel Crazy Rich Asians correlate with the result of survey about Singaporean self-improvement activities in the book entitled Understanding Singaporeans: Values, Lifestyle, Aspirations and Consumption Behaviours by Keng et al.

\section{A.4. Various Charity, Social Work, and Community Activities}


Based on the book Understanding Singaporeans: Values, Lifestyle, Aspirations and Consumption Behaviours by Keng et al, the respondents with a personal monthly income of more than $\$ 5000$ have a higher percentage of whole activities. Especially, fundraising activity in a group of high income has a total percentage about $28,2 \%$ while only $13,6 \%$ on a group who earned less than $\$ 1000$ engaged at fundraising (Keng et al., 2004: 118). It because "the availability of time and money for the higher income group" (Keng et al., 2004: 118). Singaporean who earned more than $\$ 5000$ monthly income consumed their time by fundraising. It is reflected in the novel Crazy Rich Asians by Kevin Kwan. "Charlotte, why don't you go over and invite him to your fundraiser on Saturday?" (Kwan. 2013: 17). This is a dialogue between Charlotte Lim and her mother. Mrs. Lim asked Charlotte to invite Nicholas Young to attend her fundraiser. It is evident that a fundraiser is a frequent activity for those characters.

The other data about fundraiser as a leisure activity in the novel Crazy Rich Asians is, "Grand or not, I think Astrid is wonderful," Carol chimed in. "You know, I'm not supposed to say, but Astrid wrote the biggest check at the fund-raiser..." (Kwan. 2013:26). This quotation is coming from Datin Carol. Kevin Kwan was not making a story about fundraiser on the novel specifically. He mentioned fundraiser in a dialogue to described certain character. In the quotation of Datin Carol, she described Astrid as a character who attended fundraiser. Then, Astrid also a character who wrote the biggest check at the fundraiser. It means Astrid has the availability of time and money. Through the data, the researcher found that fundraiser is a common activity in several characters in the novel Crazy Rich Asians.

In addition, visit charity activity in a group of high income has a total percentage about $15,4 \%$ while only $7,5 \%$ on a group who earned less than $\$ 1000$ engaged at visit charity (Keng et al., 2004: 118). This fact is reflected in the novel Crazy Rich Asians. Kwan mentioned charity events in several parts of the story, "Carol simply felt obligated to attend a few charity galas every week as any good born-again Christian should, and because ger husband kept reminding ger that "being Mother Teresa is good for business" (Kwan, 2013:25). This is a quotation by Datin Carol. Generally, she thought that attending charity is her responsibility. It means Datin Carol frequently coming to charity galas as she said that charity galas are her every week activity. Then, Carol's husband assumed that it will help for business.

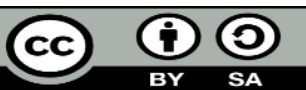


The other data that shown visit charity as a leisure activity in the novel Crazy Rich Asians is, "she had been dragged to Churchill Club for a charity fashion show organized by one of her Leong cousins..." (Kwan, 2013: 205). The statement describes a character named Astrid Leong. As the researcher explained, Kwan created the Leongs family as a super-wealthy characters in the novel Crazy Rich Asians. Attending charity is one of the ways to consume their leisure time. It is relevant to the survey on the Values, Lifestyle, Aspirations and Consumption Behaviours by Keng et al. Singaporeans who earned high income is choosing to visit charity as their leisure activity (Keng et al., 2003: 118).

\section{A.5. Travel Activities}

The result of a survey in the book entitled Values, Lifestyle, Aspirations and Consumption Behaviours by Keng et al. Singaporean who categorized as a group on high income has a higher percentage than the lower-income in several travel activities, such as visit spas (16,7\%), farm stays $(12,8 \%)$, and backpacking overseas (16,7\%) (Keng et al., 2004: 123). It is reflected in the novel Crazy Rich Asians. Especially, the visit spa activity. The result showed that it is about 16,7\% of respondents with personal monthly income more than $\$ 5000$ engaged visit spa as leisure activity (Keng et al, 2004: 123). This is several data in the novel Crazy Rich Asians that reflected the result of spa visit as travel activity based on personal monthly income on Values, Lifestyle, Aspirations and Consumption Behaviours by Keng et al.

"Who else wants to come to Shenzhen this weekend? Carol, are you in?" Eleanor asked, hoping that Carol could be roped in and they would get to use her plane. Carol leaned over from her bed and said, "I'll check, but I think we can take the plane if we leave before the weekend. I know my husband has to fly to Beijing to take over some Internet company called Ali Baibai earlier in the week. And Bernard's using the plane for Colin Khoo's bachelor party on Saturday." "Let's go to Shenzhen for ladies' spa weekend!" Nadine declared. "I want to go to that place where they soak your feet in those wooden buckets and then massage them for an hour"

(Kwan, 2013: 109)

Based on that statement, the researcher knew that Eleanor and her friends are able to categorize as a group of high income. Kwan did not mention the personal monthly income in each character. In this case, he displayed the pecuniary strength through the transportation that Eleanor and her friends will be using. In conclusion, the researcher suggested that Eleanor and her friends are a group of high 
income. It will be a data of leisure activity of a group with personal monthly incomemore than $\$ 5000$ reflected in Singapore in the novel Crazy Rich Asians.

\section{A.6. Home Entertainment Activities}

The result of a survey in the book entitled Values, Lifestyle, Aspirations and Consumption Behaviours by Keng et al, "the proportion of respondents who earned more than $\$ 5000$ registered the highest participation rate for activities such as reading $(71,8 \%)$, gardening $(24,4 \%)$, and playing a musical instrument (11,5\%)" (Keng et al, 2004: 128). Then, the researcher is used this result as a tool to find data of leisure class reflected in Singapore in the novel Crazy Rich Asians. The researcher is limiting a scope in home entertainment activities of high-income groups on the highest percentage activities, there are reading, gardening, and playing a musical instrument.

In the novel Crazy Rich Asians, the researcher found data that represent reading as leisure activities. The first data is coming from Eleanor friends- Daisy Foo, Lorena Lim, and Nadine Shaw. Kwan created a situation about their Bible study regulars. The re searcher foundEleanor and her friends spent their leisure time by analyzing a Bible. "Here, sheltered from the harsh equatorial heat, these longtime friends would sprawl languorously about the room, analyzing the Bible verses assigned in their study guides" (Kwan, 2013: 23). According to a quotation, the researcher is finding data about reading as a leisure activity. However, the researcher also gets information that represents a character of leisure class based on the theory of leisure class by Veblen. "These longtime friends would sprawl languorously about the room... (Kwan, 2013: 23)" is the evidence of the characteristic of the leisure class.

The second data is about gardening as a leisure activity in the Singaporean high-income group. On the result of the survey, there are $24,4 \%$ respondents with a personal monthly income of more than $\$ 5000$ while only $17,6 \%$ who earned less than $\$ 1000$ engaged in gardening (Keng et al., 2004:128). This is data about gardening as a leisure activity of group high income reflected in Singapore in the novel Crazy Rich Asians. "As they approached the grove, a most curious sight awaited Rachel: Nick's ninety-something-year-old grandmother stood at the top of a wooden ladder that leaned precariously against the trunk of a tall star-fruit tree, painstakingly fussing over some plastic bags. Two gardeners stood at the foot of the rickety, holding it steady, while a Gurkha and the two Thai lady's maids looked placidly" (Kwan, 2013:332-333). This quotation described

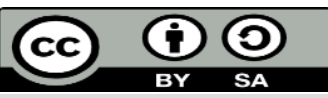


a gardening activity by Nick's grandmother, Shang Su Yi. Kwan created gardening as Shan Su Yi favorite leisure activity.

The third data is about playing a musical instrument as home entertainment activities of Singaporeans who coming froma group of high income. "A melodious peel rang through the room. Rachel turned to see an elderly woman in a white cheongsam top and black silk trousers playing a small silver xylophone by the stairs" (Kwan, 2004: 180). This quotation is not directly presenting a group of Singaporean high-income who playing music instruments. On the other hand, Kwan created a Singaporean wealthy character who invites professional music player to entertain them. These quotations are coming from Shang Su Yi's tan hua exhibition. This is evidence that Kwan created a story based on the real condition of Singapore. Since, these data correlate with the result of a survey on the book entitled Values, Lifestyle, Aspirations and Consumption Behaviours by Keng et al.

\section{B. Other Activities}

Based on the book entitled Values, Lifestyle, Aspirations and Consumption Behaviours by Keng et al "the proportion of respondents who earned more than $\$ 5000$ registered the highest participation rate for activities such as strolling/walking $(47,6 \%)$, attend religious services $(28,2 \%)$ and visit private club/country club (38,2\%)" (Keng et al., 2004: 133). However, the researcher focused on the visit private club/country club. Based on the result, it is about $38,2 \%$ of respondents with personal monthly income more than $\$ 5000$ visited private/country club while only $8,5 \%$ of respondents who coming from a group less than $\$ 1000$ visited private/country club (Keng et al., 2004: 133). It is "due to the high cost of joining a private club in Singapore" (Keng et al., 2004: 133).

In the novel Crazy Rich Asians, the researcher found data that represent visiting private/country club as leisure activities. This is a data about visiting private/country club as a leisure activity in Singaporean high income group reflected in the novel Crazy Rich Asians: "It was Nicholas Young. Even though she was only fifteen at the time, Celine Lim never forgot the day Nicholas strolled past their table at Pulau Club* and flashed that devastating grin of his at her sister Charlotte" (Kwan, 2013: 16-17). 
In addition, Kwan described a definition of Pulau Club in the footnote. He explained Pulau Club as "Singapore's most prestigious country club (with membership practically harder to obtain than knighthood)" (Kwan, 2013:17). This data contains the fact about joining a private/country club requires a high cost (Keng et al., 2004: 133). Through the data, the researcher is able to know that Kwan mentioned joining the private club as a leisure activity in his novel. Nick Young is a character who reflects a person from the high-income group. He is joining the Pulau club as his leisure activity. It is the fact about conspicuous leisure and consumption as signals of leisure class reflected in Singapore in the novel Crazy Rich Asians.

\section{Consumerism Of Leisure Class In Singapore Reflected In Kevin Kwan's Crazy Rich}

\section{Asians}

In this study, the researcher discussed the consumerism of leisure class in Singapore reflected in the novel Crazy Rich Asians. The analysis used the concept of conspicuous consumption and conspicuous leisure by Veblen. The researcher applied the information of Singaporean consumer behaviors based on the book The Cult of the Luxury Brand: Inside Asia's Love affair with Luxury by Chadha and Paul Husband. The researcher is divided a discussion into two parts. Firstly, the explanation about a consumerism of leisure class. Secondly, the discussion about Singaporean consumer behavior. The researcher is used the concept of the uniquely Singaporean mindset by Chadha and Paul Husband.

\section{C.1. The Consumerism of Leisure Class}

In this section, the researcher focused to discover the conspicuous consumption of leisure class reflected in Singapore in the novel Crazy Rich Asians. Besides the data of Francesca Shaw, the researcher also found several data on the novel that represent the consumption of luxuries goods. Kwan explained how leisure class in Singapore consumes the luxuries goods as evidence to prove their wealth.

...admiring the delicate Grecian folds of Astrid's buttercup-yellow gown.

"Wait a minute...is this an original Madame Grès?" Nathalie asked, realizing that she had seen a similar dress at the Musèe Galliera.

"From her early period," Astrid replied.

"But of course. My goodness, Astrid, you've outdone yourself once again. How on earth did you get your hands on an early Grès?" Nathalie asked in awe.

(Kwan, 2013:42) 
According to the quotation, the researcher found out the correlation to the concept of conspicuous consumption. Astrid Leong used the luxury brand to gain self -esteem from the other. Nathalie represents the observers that notice the brand of Astrid's dress. In the quotation, Kwan created how Nathalie is admiring Astrid Leong's appearances. Through the data, the researcher is able to know that Astrid is Singaporean who used foreign products Madame Grès. This brand is a luxury brand from Paris (peoplepill.com, "Madame Grès"). Astrid Leong also said that her dress is an early collection of Madame Grès. It means her dress is not only exclusive but also rare. Nathalie was more impressed by that fact. In this case, Astrid Leong is the picture of Singaporean leisure class who used luxuries goods as the mark of pecuniary strength.

\section{C.2. The Uniquely Singaporean Mindset}

In the book entitled The Cult of the Luxury Brand: Inside Asia's Love affair with Luxury, the author mentioned Singaporeans are obsessed with the price of everything (Chadha and Paul Husband, 2006: 201). Even though, Singaporeans used luxuries good as their way of life. They are still concerned about price. It is called "kiasu, fear of losing out" (Chadha and Paul Husband, 2006: 204). They love a "bargain and flaunting wealth both at once" (Chadha and Paul Husband, 2006: 204). The researcher gets a conclusion that Singaporeans are obsessed with luxuries goods as a mark of the wealthy. On the other hand, they have still cared about the price. The researcher found out the data in the novel Crazy Rich Asians represents the fact about Singaporean leisure class who love a bargain. This is the data:

"How about fifteen thousand?" Lorena asked. "Okay, for you, twenty thousand," Mr. Wong countered.

"Fifteen thousand, and that's our last offer," Lorena insisted again.

"Okay, seventeen thousand five hundred, but that's my last offer," the man said, getting frustrated by all the bargaining. Mr. Tin had told him that these ladies were millionaires.

"No - ten thousand, or I leave," Eleanor suddenly declared in Mandarin (Kwan, 2013:272).

This dialogue is between the detective named Mr. Wong and Eleanor Young's friend, Lorena. They discussed the price of the information about Rachel Chu. This is the evidence that Kwan puts the uniquely Singaporean mindset in the novel Crazy Rich Asians. Eleanor and her friends are the representation of Singaporean milliarder who are loving a bargain. 


\section{CONCLUSION}

From the discussion above, the researcher can conclude the Veblen's theory of leisure class is suitable with the consumerism of leisure class in Singapore in Kevin Kwan's crazy Ruch Asians. There are seven conspicuous leisure and consumption as the signals of leisure class in Singapore in Kevin Kwan's Crazy Rich Asians. There are sports activities, social and cultural activities, self improvement activites, various charity activities, travel activities, home entertainment activities, other activities. In each conspicuous leisure, this research is able to identified the leisure class in Singapore in the novel Crazy Rich Asians. There are conspicuous leisure and consumption as the signals of consumerism of leisure class in Singapore in Kevin Kwan's Crazy Rich Asians. Then, this study is able to identify the uniquely Singaporean mindset in the novel Crazy Rich Asians. In addition, the researcher willing this research help to others who will research in the same field. Expectantly this research could be a reference for other researchers. Moreover, the researcher realizes this research has many absences in analysing and typing the research. Hopefully, the next researcher could add some related material due to complete and broad research.

\section{REFERENCES}

[1] Abrams, M.H. 1953. The Mirror and the Lamp: Romantic Theory and the Critical Tradition. London: Oxford University Press.

[2] Babbie, Earl. 2014. The Basics of Social Research. Belmont, California: Wadsworth Cengage [3] Chadha, Radha, and Paul Husband. 2006. The Cult of Luxury Bran: Inside Asia 's Love Affair with Luxury. London, Boston: Nicholas Brealey International

[4] Keng, Kau Ah, et al. 2004. Understanding Singaporeans: Values, Lifestyle, Aspirations and Consumption Behaviours. Singapore: World Scientific Publishing Co. Pte. Ltd [5] Kevin, Kwan. 2013. Crazy Rich Asians. United States: Anchor Book 
[6] Laurenson, Diana, and Alan Swingewood. 1972. The Sociology of Literature. New York: Schocken Books Inc

[7] Pratiwi, Nofiana A. 2018. The Struggle of the Main Character to Regain his Love as Reflected in Kevin Kwan's Crazy Rich Asian: an Objective Approach. Yogyakarta: Ahmad Dahlan University

[8] Putri, Desi E, et al. June 2016. A Study of Code Mixing in English Novel Entitled Crazy Rich Asian by Kevin Kwan. Jurnal Ilmiah Sastra vol. 4, no.1

[9] Rohmawati, Dwi. 2018. Family Conflict Reflected in Kevin Kwan's Crazy Rich Asian (2013): A Sociological Approach. Surakarta: Muhammadiyah University of Surakarta

[10] Veblen, Thorstein. 1899. The Theory of the Leisure Class. United States: Macmillan [11] Winantian, Antonio. 2019. The Representation of Chinese Characters in Kevin Kwan's Crazy Rich Asian (2013). Bandung: Indonesia University of Education.

\section{Online Sources}

[1] peoplepill.com. (2020, July). Madame Grès. www.peoplepill.com/people/gres/

[2] santandertrade.com. (2020, June). Singapore: Reaching the Consumer. www.santandertrade.com/en/portal/analyse-markets/singapore/reaching-the-consumers

[3] Constance, Wu. (Nov, 2019). Kevin Kwan by Constance Wu. www.time.com/collection/mostinfluential-people-2018/5238169/kevin-kwan/

[4] Dubey, Arjun. (Mar. -Apr, 2013). Literature and Society. IOSR Journal Of Humanities And Social Science(IOSR-JHSS), vol.9, issue. 6, 2013, pp. 84-85. JSTOR, www.Iosriournals.org.

[5] Forbes. (Apr, 2020). \#1 18 Zhan Yong. Forbes, 25 Apr. 2020, www.forbes.com/profile/zhangyong-1/\#3d223bd850f7

[6] Forbes. (Apr, 2020). \#136 Robert \& Philip Ng. www.forbes.com/profile/robert-philipng/?list=rtb/\#215ff7cd5677

[7] Harper's Bazaar. (Aug, 2018).These are the Real 'Crazy Rich Asians'| Harper's Bazaar. www.youtube.com/watch?v=g01YnqH-2ek

[8] McClintock, Pamela. (March 2018). Crazy Rich Asians'Becomes Most Successful Studio RomCom in 9 Years at the U.S. Box Office. www.hollywoodreporter.com/news/crazy-rich-asiansbecomes-successful-\%20studio-rom-9-years-1139353\%20

[9] Milken Institute. (July, 2018). A Conversation with Crazy Rich Asian Author Kevin Kwan. www.youtube.com/watch?v=k26Q1XI6Rpk\&t=289s.

[10] Steinert-Lieschied, M.A. Oliver. (2006). The Representation of Veblen's Concept from the "Theory of the Leisure Class" in Dreisers "Sister Carrie". www.grin.com/document/145306
[11]
Philips,
Ronnie. (July,
2019).
Conspicious
Consumption. www.britannica.com/topic/conspicuous-consumption

[12]@kevinkwanbook. "The \#CrazyRichAsians trilogy is now available in over thirty languages around the world." Instagram, 27 Mar. 2019, www.instagram.com/p/Bvev6LoFCtc/?igshid=ntl8a4k47lql.

[13] @kevinkwanbook. "Loving that the Top 4 books on the LA Times Bestseller List this week..." Instagram, 27 Mar. 2019, www.instagram.com/p/Bj5OXO4FcCD/?igshid=14ssbcmwqbf68.

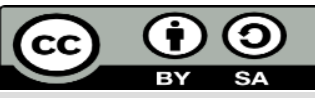


[14]@kevinkwanbook. “... "Crazy Rich Asian s” is \#4th on New York Times Bestseller List this week!!!” Instagram, 3 May 2018, www.instagram.com/p/BiUdl1bFBzG/?igshid=1149c3swy217a. [15]@kevinkwanbook. "No.1 movie in America this weekend. Top opening comedy of the year. Highest grossing romantic comedy debut since 2015..." Instragram, 20 Aug. 2018, www.instagram.com/p/BiUdl1bFBzG/?igshid=1149c3swy217a. 